-

Global Journals Inc

(2)

GLOBAL JOURNAL OF MANAGEMENT AND BUSINESS RESEARCH: G

INTERDISCIPLINARY

Volume 19 Issue 4 Version 1.0 Year 2019

Type: Double Blind Peer Reviewed International Research Journal

Publisher: Global Journals

Online ISSN: 2249-4588 \& Print ISSN: 0975-5853

\title{
People-Related TOM Practices, Organisational Culture, Organisational Justice and Employee Work-related Attitudes for Quality Performance: A Research Agenda
}

By Shaguntala Durairatnam, Siong-Choy Chong \& Mazuki Jusoh

University of Sri Jayewardenepura

Abstract- Total Quality Management (TQM), adopted by organizations to improve performance, has often been reported to have failed. This paper reviews people-related TQM practices, organizational culture, organizational justice, and employee work attitudes (job satisfaction, turnover intention, and job involvement) to gain further insights into implementing TQM to yield anticipated quality performance. Employee work-related attitudes are posited as mediators in the relationship between people- related TQM practices and quality performance. In a unique contribution, the paper conceptualizes the synergistic effect of people-related TQM practices and other people-related factors (organizational culture and organizational justice) as predictors of enhanced employee work-related attitudes and quality performance.

Keywords: people-related TQM, organizational culture, organizational justice, employee attitudes, quality performance, mediations, synergies.

GJMBR-G Classification: JEL Code: D23, M14

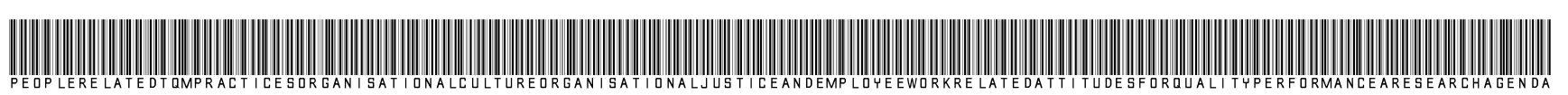

Strictly as per the compliance and regulations of:

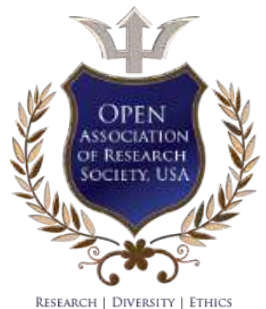

(c) 2019. Shaguntala Durairatnam, Siong-Choy Chong \& Mazuki Jusoh. This is a research/review paper, distributed under the terms of the Creative Commons Attribution-Noncommercial 3.0 Unported License http://creativecommons.org/licenses/bync/3.0/), permitting all non-commercial use, distribution, and reproduction in any medium, provided the original work is properly cited. 


\title{
People-Related TQM Practices, Organisational Culture, Organisational Justice and Employee Work-related Attitudes for Quality Performance: A Research Agenda
}

\author{
Shaguntala Durairatnam ${ }^{\alpha}$, Siong-Choy Chong ${ }^{\sigma} \&$ Mazuki Jusoh ${ }^{\rho}$
}

\begin{abstract}
Total Quality Management (TQM), adopted by organizations to improve performance, has often been reported to have failed. This paper reviews people-related TQM practices, organizational culture, organizational justice, and employee work attitudes (job satisfaction, turnover intention, and job involvement) to gain further insights into implementing TQM to yield anticipated quality performance. Employee work-related attitudes are posited as mediators in the relationship between people- related TQM practices and quality performance. In a unique contribution, the paper conceptualizes the synergistic effect of people-related TQM practices and other people-related factors (organizational culture and organizational justice) as predictors of enhanced employee work-related attitudes and quality performance.
\end{abstract}

Keywords: people-related TQM, organizational culture, organizational justice, employee attitudes, quality performance, mediations, synergies.

\section{INTRODUCTION}

T he importance of quality to organizations in the present competitive and globalized business environment is well understood. Total Quality Management (TQM) was conceptualized as an approach to achieve high-quality performance and customer satisfaction. This philosophy, born almost four decades ago, has today penetrated diverse business organizations. Through ISO certification systems and other approaches, various business sectors implemented TQM on the premise that it provides strategic advantages in the marketplace. This belief is based on the prescriptions of the quality gurus (such as Deming, Juran, Crosby and Ishikawa), supported by vast body of research on positive impact of TQM on quality performance (Ahmad et al., 2018; Gupta, Garg \& Kumar, 2018; Nair, 2006; Shafiq, Lasrado \& Hafeez, 2017; Yeung, 2008, Zu, 2009). However, amidst the plethora of empirical evidence on the positive

Author a: Management and Science University (MSU), Malaysia. Postgraduate Institute of Management, University of Sri Jayewardenepura, Sri Lanka.

e-mails: sakunthala.durairatnam@yahoo.com, sakunthala@pim.sjp.ac.lk

Author o: Finance Accreditation Agency, Malaysia.

e-mail: eddyscchong@yahoo.com

Author p: Management and Science University (MSU), Malaysia. e-mail:keyjus@yahoo.com implications of TQM, there are also several contradictory views (Benner \& Veloso, 2008; Dubey et al., 2017; Jayaram et al., 2010; Jun et al., 2006; Menezes, 2012), illustrating the failure of TQM initiatives to consistently result in enhanced quality performance.

Attempting to explain this inconsistency, many scholars (Davis, Coole \& Smith, 2017; Hackman \& Wageman, 1995; Manz \& Stewart, 1997; Zeng, Zhang, Matsui \& Zhao, 2017) have described TQM as a sociotechnical system. While the technical systems are more standardized, it is the social system which is prone to variations that causes the inconsistencies in TQM results (Douglas \& Judge, 2001; Jun, Cai \& Shin, 2006; Khan, Malik \& Janjua, 2019; Montes et al., 2003; Wei et al., 2017). In TQM literature, the social system factors have also been described in varied terms such as soft TQM (Rahman \& Bullock, 2005; Ooi et al., 2005), peoplerelated TQM (Prajogo \& Cooper, 2017, 2017) and infrastructure TQM (Flynn et al., 2005). Previous studies have reported that implementation of 'soft' or peoplerelated TQM will first result in 'soft', i.e., people-related work attitudes, which will, in turn, facilitate the 'hard', i.e., quality, operational and financial outcomes (Adawiyah, 2012; Rahman \& Bullock, 2005). The importance of people-related aspects in previous research in explaining inconsistencies in quality performance, directs this paper to focus on people-related TQM practices and intermediary people-related TQM results, which are the employee work-related attitudes. Although the need for studying the mediational role of employee work attitudes was identified (Hackman \& Wageman, 1995; Montes et al., 2003), this area has not received much attention. This paper attempts to establish the potential mediation effect of employee work attitudes in the relationship between people- related TQM practices and quality performance.

TQM proponents have advocated viewing of TQM philosophy, from a holistic perspective, as an organization-wide initiative (Hackman \& Wageman, 1995; Prajogo \& Cooper, 2017). Employees who are exposed to similar practices and policies under the TQM program are more likely to develop shared perceptions, which culminate in a TQM climate in the organization. 
The shared perceptions regarding TQM practices, create positive employee attitudes such as job satisfaction (Prajogo \& Cooper, 2017). A scarcity is noted in studies examining the effect of similar TQM climate on other employee work attitudes such as turnover intention and job involvement. It was suggested that people-related factors such as organizational culture (Prajogo \& McDermott, 2011; Valmohammadi \& Roshanzamir, 2015) and organizational justice (Mohamed, 2014) contribute towards enhancing positive employee attitudes and performance in a TQM setting. However, only a few studies (for example, Bhakshi et al., 2009; Khan et al., 2015; Kim et al., 2017) have focused on the roles of these factors. This paper will address the potential of organizational culture and organizational justice perceptions in driving quality performance through enhanced work attitudes.

Powell (1995) examines TQM as a potential source of competitive advantage viewed from the resource-based view (RBV) perspective. Nevertheless, there is paucity of studies on synergistic effect of TQM practices and other people-related factors in predicting quality performance and employee work-related attitudes. This paper argues that there exist synergistic effects of PTQM practices and other non-imitable resources in building a competitive advantage. These resources, such as organizational culture and organizational justice perceptions acting in synergy with TQM are posited as predictors of augmented employee work-related attitudes and quality performance.

Literature reveals the need to further investigate people- related TQM practices, organizational culture, and organizational justice as drivers of employee work attitudes and quality performance. In addition, mediating role of employee attitudes and the potential synergistic effect of PTQM practices, organizational culture and organizational justice in enhancing employee work attitudes and quality performance needs examination. This paper aims to conceptualize above mentioned relationships to address the research gaps.

Organization of the rest of the paper is as follows. People- related TQM practices, organizational culture, organizational justice, employee work-attitudes (job satisfaction, job involvement, and turnover intention), and quality performance, are reviewed. The paper, then postulates potential relationships for an integrated model to test the proposed relationships. The paper concludes with directions for future research.

\section{Literature ReVIEW}

The following sub-sections review the literature on relationships between PTQM practices, employee work attitudes, and quality performance.

a) TQM practices and performance

TQM is an integrated approach to achieving and sustaining high- quality output. As defined by Dean and Bowen (1994), TQM focuses on the maintenance and continuous improvement of processes and defect prevention at all levels and in all functions of the organization to meet or exceed customer expectations. The association between TQM practices and performance has been well-established (Anil \& Sathish, 2019; Ahmed et al. 2018; Mehralian et al., 2017; Nair, 2006; Patyal \& Koilakuntla, 2017; Sousa \& Voss, 2002 among others). There is consensus in TQM literature that TQM practices comprise of two dimensions. The first is 'hard' TQM practices, also referred to as core practices. The second dimension comprises of the 'soft' TQM practices, known as infrastructure practices (Flynn et al., 1995; Fotopoulos \& Psomas, 2009; Lewis et al., 2006; Vouzas \& Psyhogios, 2007) which contains people and culture-oriented practices. Soft practices are termed as 'people-related TQM practices' in the studies by Prajogo and Cooper $(2010,2017)$ and Chathurika and Dileepa (2016). The proponents of the importance of soft TQM (e.g., Prajogo \& Cooper, 2010, 2017; Ooi et al., 2005; Rahman \& Bullock, 2005) claim that such practices empower and support employees to maximize their potential in contributing to high -quality outcomes. A conducive environment is created where the "hard" TQM is easily implemented. The PTQM practices of focus in this paper follow the study of Prajogo and Cooper $(2010,2017)$ and Ooi et al. (2005). They include top management commitment, employee empowerment, employee involvement, training, and teamwork.

Quality performance refers to the quality of products and services, process variability, delivery, cost of scrap and rework, cycle time, and customer satisfaction (Zu et al., 2009). TQM implementation and the resulting performance are explained by scholars, based on Socio-Technical Systems (STS) theory of Trist and Bamforth in 1951 (Manz \& Stewart, 1997). The STS theory relies on the premise of joint optimization between social and technical considerations rather than emphasizing one over the other. Maximum performance can be achieved only through joint consideration of social and technical aspects (Pasmore, 1995).

b) People- related TQM practices and employee workrelated attitudes

The immediate outcomes of TQM implementation are employee work-related attitudes (Morrow, 1997; Prajogo \& Cooper, 2010; Sadikoglu \& Zehir, 2010). Karia and Aasari (2006) stress that TQM produces positive effects on employees by improving their satisfaction and commitment and thereby enhancing organizational effectiveness. Employee attitudinal outcomes identified in the extant TQM literature include job satisfaction (Amin, 2017; Arunachalam \& Palanichamy, 2017; Chathurika \& Dileepa, 2016; Chen \& Ayree, 2007; Karia \& Assari, 2006; Molina et al., 2014; Mosadeghrad, 2014; Ooi et 
al., 2000; Prajogo \& Cooper, 2010, 2017; Wickramasinghe, 2012), turnover intention (Guchait \& Cho, 2011, Yee, Ooi \& Keong, 2011), and job involvement (Tang, Chen \& Wu, 2010; Ooi, Arumugam \& Teo, 2005).

The growing interest in employee job satisfaction has led to studies on antecedents and consequences in TQM literature (Matzler, Fuchs \& Schubert, 2004). Chang, Chiu, and Chen (2010) argue that satisfied employees tend to be more loyal to the organization and that a loyal workforce is a pre-requisite for successful TQM implementation. Among the factors emphasized as drivers of job satisfaction in the TQM domain, are training and development, leadership, teamwork, employee participation, and employee empowerment (Ahire, Golhar, \& Waller, 1996; Chang, Chiu \& Chen, 2010; Ooi, Arumugam, \& Teo, 2005). On the contrary, some studies do not discover any significant correlation between these two variables (Daily \& Near, 2000; Mohr \& Puck, 2007). The premise that TQM poses high pressure working environments (Menezes, 2012) leads to questioning of the association between TQM practices and job satisfaction, reporting a negative relationship between process management in TQM and job satisfaction (Akdere, 2009). The focus on job satisfaction as an outcome of TQM practices has received increasing attention. (e.g., Chathurika \& Dileepa, 2016; Karia \& Assari, 2006; Ooi et al., 2007; Prajogo \& Cooper, 2017; Sadikoglu \& Zehir, 2010). However, studies investigating job satisfaction arising from TQM implementation are limited in scope. The impact of increased job satisfaction on quality performance was not empirically tested in the TQM context.

Turnover intention is interpreted as the desire of employees to voluntarily change companies or employers, or the desire to willingly terminate the organizational membership that will end the employeremployee relationship (Yue, Ooi \& Keong, 2011). Yue et al. (2011) also reported on the substantial empirical studies conducted regarding the positive influence of TQM practices on turnover intention. Employees' participation in organizational quality initiatives enhance their affective response resulting in higher job satisfaction and greater intent to stay (Gardner \& Carlopio, cited by Yue et al., 2011). Hence, the implementation of TQM improves turnover intention (Guimeraes, 1997). Specifically, human resourcesfocused TQM practices such as employee empowerment and teamwork have been found to have a positive and significant influence on employee satisfaction, leading to higher levels of loyalty and lower turnover intention (Jun et al., 2006). Despite the widespread consensus that TQM is a way of managing organizations to improve quality performance, there is less agreement on the contribution of TQM in improving in job satisfaction and turnover intention (Yue, Ooi \&
Keong. 2011) indicating the need for further empirical studies to reinforce the relationships.

$\mathrm{Job}$ involvement is the level of psychological identification of an individual with a specific job in which he or she is engaged (Wickramasinghe \& Wickramasinghe, 2011). On the one hand, individuals, highly involved with their jobs, extend more time and effort into their jobs (Huang et al., 2016). On the other hand, employees exhibiting low job-involvement tend to leave the organization, withhold work effort, or engage in various undesirable on-the-job activities. Job involvement is studied in the TQM context, albeit sparingly. The studies in this area include Karia and Aasari (2006), Ooi et al. (2005), and Karia and Ahmad (2000), reporting that soft TQM practices such as training, teamwork, empowerment have significant relationships with job involvement. However, studies investigating job involvement in the TQM context are limited to identifying whether TQM practices act as antecedents of job involvement. The Investigation into its consequences in TQM settings shows neglect.

Based on the literature, employee work-related attitudes, the immediate outcomes of PTQM implementation are delineated. The following subsection presents a literature review of organizational culture and its established link to employee work-related attitudes and its potential as a driver of performance at the employee and organizational level.

c) Organizational culture, employee work attitudes, and quality performance

Organizational culture distinguishes one organization from another (Prajogo \& McDermott, 2011). Organizational success requires building a supportive corporate culture (Mosadeghrad, 2014), providing a foundation for implementing TQM (Kaluarachchi, 2010; Mosadeghrad, 2006; Wardhani et al., 2009). Siehl and Martin (1990) propose that culture potentially has a direct effect on factors such as morale, commitment and job satisfaction. The 'intermediaries' influence organizational effectiveness. In contrast, cultures that emphasize on formal structures, regulations are negatively associated with quality improvement activities (Ferlie \& Shortell, 2001). Numerous studies highlighted that cultural variables drive TQM success (Dean \& Bowen, 1994; Hackman \& Wageman, 1995; Katz et al., 1998; Kujala \& Lillrank, 2004; Metri, cited by Prajogo \& McDermott, 2011; Tata \& Prasad, 1998; Powell, 1995; Mosadeghrad, 2006). Accordingly, TQM programs would succeed if the organizational culture is compatible with the TQM discipline (Kujala \& Lillrank, 2004).

The Competing Values Framework (CVF) has been popularly used to represent the multidimensionality of organizational culture. This framework considers specific relationships between different cultural dimensions and types of performance 
(Prajogo \& McDermott, 2011). Developed by Quinn and Spreitzer (1991), CVF captures four cultural dimensions along two axes. The first axis contains flexibility-control, and the other axis describes development vs. stability. Combining these dimensions presents four quadrants, each representing a unique cultural type, namely group, developmental, hierarchical, and rational (Leonard, 2015). The CVF culture dimensions have been shown to influence varied outcomes at the employee and organizational levels. For example, Prajogo and McDermott (2011) state that flexibility and control are critical for testing whether underlying cultures prompt the pursuit of different strategic goals in terms of quality. Rational culture, oriented towards control and external activities, is positively related to product quality. Kim et al. (2017) reported that authoritarian organizational culture (which is comparable with the hierarchical culture domain of CVF), impairs the organizationemployee relationship quality and thereby positively influences turnover intention.

This paper conceptualizes different dimensions of organizational culture as predictors of employee work-related attitudes and quality performance. The ensuing sub-section seeks to understand whether organizational justice, another important people-related factor in the TQM domain, has similar predictor potential.

d) Organizational justice, employee work attitudes, and quality performance

Organizational justice is an umbrella term used to refer to the perceptions of individuals on the fairness of decisions, decision-making processes within organizations and the influences of those perceptions on behavior (Lavell, Rupp \& Buckner, 2001). Organizational justice has been operationalized as three specific types, namely distributive justice, procedural justice, and interactional justice (Bryne \& Cropanzano, 2001). The impact of organizational justice perceptions on performance is believed to stem from equity theory (Adam, 1963). Accordingly, when employees perceive injustice, they seek to restore justice, mainly by altering their level of performance. Employees who believe that they are treated fairly are more likely to undertake tasks that go beyond the minimum expectations of their position and to work diligently to solve organizational problems (Aselage \& Eisenberger 2003).

As stated by Bryne (2005) and Hamid (2009), fair treatment has significant effect on individual employee attitudes (satisfaction, absenteeism, turnover intention, organizational citizenship behavior, and job performance). Mohamed (2014) reported a positive correlation between organizational justice components and quality performance. Previous studies indicate that the employee perception of organizational justice is a key predictor of positive work attitudes including job satisfaction that may contribute to retaining them in their organizations (Bhakshi et al., 2009; Colquitt et al., 2001; Cropanzano et al., 2007; Greenberg, cited by Choi, 2011). Distributive justice and procedural justice have been found to result in increased job satisfaction and job involvement, and a negative impact on turnover intention (Khan et al., 2015; Suifan et al., 2017). Kim et al. (2017) reported that organizational justice has a positive impact on improving organization-employee relationship quality and thereby has a negative impact on turnover intention.

The literature shows that organizational justice influences performance indirectly through its impact on employee attitudes and behaviors. Studies investigating the direct relationship of organizational justice perception to firm performance are scarce. Notwithstanding, more rigorous studies are required to understand the direct and indirect influences of perceptions of all organizational justice dimensions on employee attitudes such as job satisfaction, turnover intention, job involvement, and quality performance. The literature discussed above predicts that organizational justice is an apt driver of employee work-related attitudes and quality performance.

Based on the literature reviewed above and the discussion thereon, this paper poses the following research question.

Research question 1: What are the relationships between people-related TQM practices, organizational culture, organizational justice, employee work attitudes, and quality performance?

The following propositions are formulated to test the relationships queried in the first research question.

$P_{1}$ : People-related TQM practices are related to quality performance.

$P_{2}$ : Organizational culture is related to quality performance.

$P_{3}$ : Organizational justice is related to quality performance.

$P_{4}$ : PTQM practices are related to employee work-related attitudes.

$P_{5}$ : Organizational culture is related to employee workrelated attitudes.

$P_{6}$ : Organizational justice is related to employee workrelated attitudes.

$P_{7}$ : Employee work-related attitudes are related to quality performance.

The following sub- section discusses the mediating effect of employee work-related attitudes.

e) Mediating effects of employee work attitudes

Organ (1977) used the Social Exchange Theory (SET) to explain the relationship between employee attitudes and organizational effectiveness. The mediating roles of employee work attitudes such as job satisfaction, job involvement, and turnover intention are 
based on SET, which suggests that employees engage in positive or negative behaviors in response to positive or negative actions, seen to originate from the organization. Conversely, when employees experience dissatisfying conditions, they will react by resorting to counter-productive work behaviors (Crede et al., 2007). Soft TQM practices such as participative decision making, employee empowerment, employee involvement, and training create a conducive and intrinsically motivating environment. In a TQM environment, favorable work attitudes result through the development of a supportive work environment (Flynn et al., 1995), fostering teamwork (Zhao et al., 2004) and engagement in more job related pro-social behaviors (Organ \& Konovsky, cited by Zhao et al., 2004). Based on these premises, it is postulated that favorable employee attitudes resulting from the implementation of TQM practices will, in turn, lead to improved performance.

The relationship between employee attitudes and organizational effectiveness is well supported empirically. Employee job satisfaction has been reported as a mediator for many high involvement practices and varied forms of performance (Khan, Malik \& Janjua, 2019; Otoo et al., 2019; Prasad \& Prabhudesi, 2018; Sadikoglu \& Zehir, 2010; Trivellas \& Santouridis, 2009). Gregory et al. (2009) also suggest that employee attitudes can be mediators of the relationship between organizational culture and organizational effectiveness.

In TQM literature, the vacuum in the study of the mediational role of employee work attitudes is identified by scholars (for example, Hackman \& Wageman, 1995; Montes et al., 2003; Yousef, 2000). The mediation by employee work attitudes, including job satisfaction was conceptualized by Montes et al. (2003) and was reported as partially mediated by Sadikoglu and Zehir (2010). This paper aiming to conceptualize additional insights in this regard to enrich TQM literature relating to mediating effects of employee work attitudes raises the second research question as follows.

Research Question 2: Do employee work attitudes mediate the relationships between people-related TQM practices, organizational justice, organizational culture, and quality performance?

The propositions below are posited to empirically test the potential mediating effects.

$P_{8}$ : Employee work-related attitudes mediate the relationship between people-related TQM practices and quality performance.

$P_{9}$ : Employee work-related attitudes mediate the relationship between organizational culture and quality performance.

$P_{10}$ : Employee work-related attitudes mediate the relationship between organizational justice and quality performance.
This paper has posited PTQM practices, organizational culture, and organizational justice as predictors of employee-work attitudes and quality performance. Potential mediating effects of employee work attitudes also have been suggested with literature supported. The following sub- section discusses the potential synergistic effect of the people-related drivers in enhancing the impact on employee-work attitudes and quality performance.

Synergistic effects of People-related TQM, organizational culture and organizational justice on employee work attitudes and quality performance.

In the face of intense competition in the global market, organizations face pressure to remain competitive. Therefore, organizations need to be ahead of the competition in multiple dimensions of performance, including product quality (Kanchanapong et al., 2014). Numerous studies attempted to identify the resources that drive excellent operational performance. Under the Resource-Based View (RBV) perspective, it is argued that combining different resource bundles may result in synergistic effects on operational performance (Khanchanapong et al., 2014). Powell (1995) points out that TQM is one such non-imitable resource that can produce economic advantage (Finningan, 1992). TQM creates value through a variety of improvements including, understanding customer needs, improved customer satisfaction, improved internal communication, better problem solving, higher employee motivation and commitment, stronger supplier relations, as well as reduced defects and waste (Powell, 1995).

TQM in synergy with other practices has been shown to result in enhanced performance. According to Pool (2000), TQM implementation, together with a supportive organizational culture, enhances organizational learning, suggesting the synergy between TQM and culture. This view suggests that organizational culture is a potential resource to pair with TQM to gain competitive advantage. Also, the synergistic effect of procedural justice with high-involvement HR practices was studied by Searle et al. (2011). Since highinvolvement HR practices (including employee empowerment, training, and teamwork)are comparable to people- related TQM practices, this paper posits a potential synergistic effect of people-related TQM practices and justice perceptions in enhancing employee level and organizational performance. Many studies investigated the synergistic effect between TQM and other technical and operational systems (e.g., Kaur, Singh \& Ajuha, 2013; Vupalapatti, Ahire \& Gupta, 1995; Youseff \& Youseff, 2018). However, a vacuum exists in studies of TQM with employee-related 'soft' factors. Given the importance of employees as an integral part of organizational competitiveness, it is beneficial to identify people-related factors such as culture and 
justice perceptions, which may act in synergy with TQM initiatives to enhance organizational performance.

Based on the above discussion, there arise the following research questions relevant to the TQM domain.

Research Question 3: Are there synergistic relationships between people-related TQM practices and organizational culture in predicting employee work attitudes and quality performance?

Research Question 4: Are there synergistic relationships between people-related TQM practices and organizational justice in predicting employee work attitudes and quality performance?

There is a need to empirically test whether culture, justice perceptions, and TQM exhibit synergistic effects in enhancing employee work attitudes and quality performance. The propositions below are posited to bridge the identified gaps.

$P_{11}$ : There is a synergistic relationship between peoplerelated TQM practices and organizational culture in predicting employee work-related attitudes.

$P_{12}$ : There is a synergistic relationship between peoplerelated TQM practices and organizational justice in
$P_{13}$ : There is a synergistic relationship between peoplerelated TQM practices and organizational culture in predicting quality performance.

$P_{14}$ : There is a synergistic relationship between peoplerelated TQM practices and organizational justice in predicting quality performance.

In line with the concept of RBV, it is postulated that organizational culture and organizational justice complementing people related TQM produce synergistic effects in driving competitive advantage, including quality performance. Future studies based on this perspective may yield valuable insights into the potential of such synergistic effects in enhancing employee and organizational performance.

\section{ili. Conceptual Framework}

The paper has, through literature review and discussion, identified research gaps, raised research questions, formulated hypotheses to test the potential relationships. Figure 2.1 presents an integrated model, proposed for testing employee work-related attitudes and quality performance in TQM settings.

predicting employee work-related attitudes.

People-related TQM

practices (PTQM)

\section{Organisational Culture (OC)}

\section{Organisational Justice (OJ)}

\section{PTQM x OC}

\section{PTQM x OJ}

\section{Employee work-related attitudes}

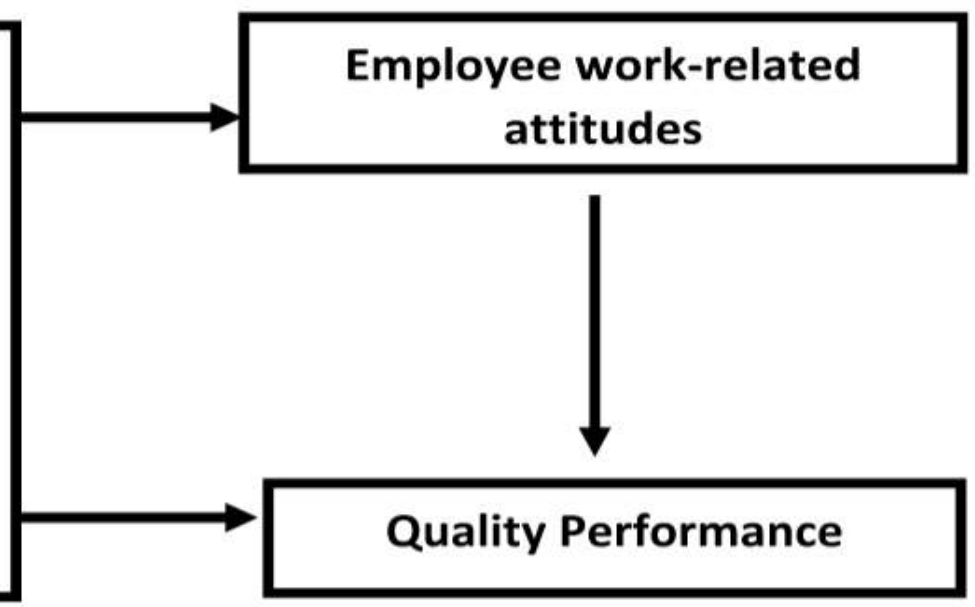

Figure 1: Conceptual Framework

\section{Discussion and Implications}

The paper prompts research into scarcely studied areas focusing on PTQM practices predicting employee work-related attitudes and quality performance. This contribution opens out a new dimension to the TQM domain, and empirical testing in varied contexts. The paper extends the extant TQM literature by incorporating concepts from the domains of organisational culture and justice. Dean and Bowen (1994), comparing the TQM literature with management theory, called for the extension of TQM by drawing from management theory and that TQM and management theory should be informed by each other on areas of vacuum. The incorporation of the organizational justice theory and CVF is a contribution towards this end.

Contributing to the need to focus on the immediate outcomes of TQM implementation (Morrow, 1997), the paper also suggests future research on relationships of employee work attitudes (job satisfaction, turnover intention, and job involvement) with people- related TQM practices, organizational culture and organizational justice. TQM, given its mission of advancing organizational performance, is prescriptive in orientation (Dean \& Bowen, 1994). Sitkin et al. (1994), commenting that TQM is led by practitioners rather than researchers, proposed that future research on TQM use theory from existing organization literature and translate 
to TQM approaches. This paper serves to make a theoretical contribution by conceptualizing TQM above the prescription level to understanding of organisational behaviors. The mediational roles of job satisfaction, turnover intention, and job involvement are theorized through the SET and are positioned as a path to explain the quality performance.

TQM was suggested as a non-imitable resource creating a competitive advantage. At the outset, the paper identified that the synergistic effects of TQM, along with other non-imitable practices of the organizations were not addressed in the TQM literature. This paper makes a significant contribution to narrow the gap by suggesting a framework for studies in this direction.

Moreover, this paper presents a universally applicable model to empirically test the factors driving quality performance and employee work attitudes. Transcending the boundaries of the traditional determinants of quality performance, the paper posits organizational culture and organizational justice as drivers of quality performance and employee work attitudes, which is a noteworthy theoretical contribution. The model extends previous studies by adding job involvement as an immediate outcome of TQM implementation.

On the practical side, the paper attempts to shift the focus of managers of TQM from a highly technical to a social orientation. The importance of employees at all levels in maximizing TQM results has been pointed out, highlighting specific employee attitudes requiring focus. Achievement of quality performance is through the mediating effect of employee work attitudes. Therefore, management attention on crafting and implementing strategies to enhance job satisfaction, job involvement, and to mitigate turnover intentions is imperative.

\section{Conclusion and Future Research DiRECTIONS}

This paper has achieved its objectives, starting with comprehensively reviewing the PTQM practices, organizational culture and organizational justice. The potential in predicting in predicting employee work attitudes and quality performance, is also postulated. Employee work attitudes are conceptualized as mediators in the relationship between people- related TQM practices, organizational culture, organizational justice, and quality performance. The synergistic relationship between people- related TQM practices, organizational culture, and organizational justice are proposed as predictors of employee work attitudes and quality performance. Based on foundations of sociotechnical systems theory, organizational justice theory, competing values framework of organizational culture, social exchange theory, and resource-based view perspectives, the paper provides an integrated approach for employee work attitudes and quality performance. The paper uniquely contributes to theoretical issues underpinning quality performance and employee work attitudes.

Organizations invest considerable resources on TQM implementation, and failure of the initiative to yield anticipated results will lead to loss of confidence in TQM philosophy. In light of the insights of the critical role of organizational culture and organizational justice in achieving quality performance, managerial focus towards embedding a conducive culture is imperative. Enriched quality performance is achieved through a focus on driving team working and developmental orientation through continuous improvement team activities. Also, putting in place policies and practices for fair distribution of rewards is a prerequisite for change initiative programs such as TQM.

This paper has suggested only three employee work attitudes as mediators, i.e., job satisfaction, turnover intention, and job involvement. Other work attitudes, such as commitment and motivation, were identified (Montes, 2003). Future studies are recommended to look at the roles of more work attitudes to gain a comprehensive understanding of how TQM works in organizations.

A research study linking the people- related TQM practices, organizational justice, organizational culture, and quality performance mediated by employee work attitudes is currently undertaken on the apparel industry in Sri Lanka. The findings will further reinforce the value of this paper, both in theory and practice. A subsequent publication will present the findings.

\section{References Références Referencias}

1. Abdullah, M.M.B. \& Tarí, J.J. (2018). Hard quality management and performance: The moderating role of soft quality management, International Journal for Quality Research, 11(3) 587-602.

2. Adawiyah, W.R. (2012). The relationship between soft TQM and organisational citizenship behaviour: A case of Islamic banks in Indonesia. International Review of Social Sciences and Humanities, 2(29), 213-226.

3. Ahire, S. L., Landeros, R. \& Golhar, D.Y. (1995). Total quality management: A literature review and an agenda for future research. Production and Operations Management, 4(3), 277-306.

4. Ahmad, M.F., Zakuan, N., Ahmad, J. \& Takala, J. (2015). Meta-analysis of the TQM impact on business performance amongst regions and countries. International Journal of Industrial and Systems Engineering, 20(2), 155-165.

5. Akdere, M. (2009). A multi-level examination of quality-focused human resource practices and firm performance: Evidence from the US healthcare 
industry. The International Journal of Human Resource Management, 20(9), 1945-1964.

6. Arunachalam, T. \& Palanichamy, Y. (2017). Does the soft aspects of TQM influence job satisfaction and commitment? An empirical analysis. The TQM Journal, 29(2), 385-402.

7. Anil, A. P. \& Satish, K.P. (2016). Investigating the relationship between TQM practices and firm's performance: A conceptual framework for Indian organisations, Procedia Technology, 24, 554-561.

8. Benner, M.J. \& Veloso, F.M. (2008). ISO 9000 practices and financial performance: A technology coherence perspective. Journal of Operations Management, 26, 611-629.

9. Bryne, Z.S., \& Cropanzano, R. (2001). Justice in the Workplace: From Theory to Practice. USA: Psychology Press.

10. Chathurika. H.J. \& Dileepa, M. E. W. (2016). Predicting employees' job satisfaction with peoplerelated TQM practices: Case in apparel manufacturing industry, Sri Lanka. Journal of Business Studies, 3(2), 1-17.

11. Chen, Z. X., \& Aryee, S. (2007). Delegation and employee work outcomes: An examination of cultural context of mediating processes in China. Academy of Management Journal, 50, 226 -238. doi:10.5465/AMJ.2007.24162389

12. Choi, M. (2011). Employees' attitudes toward organizational change: A literature review. Human Resources Management, 50 (4), 479-500.

13. Colquitt, J. A., Conlon, D. E., Wesson, M. J., Porter, C. O. L. H., \& Ng, K. Y. (2001). Justice at the millennium: Ameta-analytic review of 25 years of organizational justice research. Journal of Applied Psychology, 86,425-445,

14. Crede, M., Oleksandr, S., Chernyshenko, O.S., Stark, S., Reeshad S., Dalal, R.S. \& Bashshur, M. (2007). Job satisfaction as mediator: An assessment of job satisfaction's position within the nomological network. Journal of Occupational and Organisational Psychology, 80, 515-538.

15. Cropanzano, R., Bowen, D.E. \& Gilliland, S.W. (2007). The management of organisational justice. Academy of Management Perspectives, 21, 34-50.

16. Douglas, T.J. \& Judge, W.Q. (2001). Total quality management implementation and competitive advantage: The role of structural control and exploration. Academy of Management Journal, 44(1), 158-169.

17. Dubey, R., Gunasekaran, A., Childe, S.J., Papadopoulos, T., Hazen, B.T. \& Roubaud, D. (2017). Examining top management commitment to TQM diffusion using institutional and upper echelon theories. International Journal of Production Research, 56(8), 2988-3006.

18. Flynn, B.B., Schroeder, R.G. \& Sakakibara, S. (1995). The impact of quality management practices on performance and competitive advantage. Decision Sciences, 26(5), 659-692.

19. Gambi, L. D. N., Boer, H., Gerolamo, M. C., Jørgensen, F. \& Carpinetti, L. C. R. (2015). The relationship between organisational culture and quality techniques, and its impact on operational performance. International Journal of Operations and Production Management, 35(10), 1460-1484.

20. Gould-Williams, J. \& Davies, F., (2005). Using social exchange theory. The International Journal of Human Resource Management, 18(9), 1627-1647.

21. Guimaraes, T. (1996). TQM's impact on employee attitude. TQM Magazine, 8(1), 20-25.

22. Gupta, V., Garg, D., \& Kumar, R. (2018). Performance evaluation of TQM attainment in Indian manufacturing sector. International Journal of Services and Operations Management, 34 (4). doi.org/10.1504/IJSOM.2018.089252

23. Hackman, J. \& Wageman, R. (1995). Total quality management: Empirical, conceptual and practical issues. Administrative Science Quarterly, 40, 309-342.

24. Jayaram, J., Ahire, S. L., \& Dreyfus, P. (2010). Contingency relationships of firm size, TQM duration, unionisation, and industry context on TQM implementation - A focus on total effects. Journal of Operations Management, 28, 345-356.

25. Jun, M., Cai, S. \& Shin, H. (2006). TQM practice in maquiladora: Antecedents of employee satisfaction and loyalty. Journal of Operations Management, 24, 791-812.

26. Khan, M., Malik, S., \& Janjua, S. (2019). Total Quality Management practices and work-related outcomes. International Journal of Quality \& Reliability Management, 36 (6), 864-874.

27. Khanchanapong, T., Daniel Prajogo, D., Sohal, A.S., Cooper, B.K., Yeung, A.C.L., \& Cheng, T.C.E. (2014). The unique and complementary effects of manufacturing technologies and lean practices on manufacturing operational performance. International Journal of Production Economics, 153, 191-203.

28. Karia, N. \& Asaari, A.H. (2006). The effects of total quality management practices on employees' work-related attitudes. The TQM Magazine, 18(1), 30-43.

29. Kaur, M., Singh, K., \& Ahuja, S I. (2013). An evaluation of the synergic implementation of TQM and TPM paradigms on business performance. International Journal of Productivity and Performance Management, 62 (1), 66-84. doi.org/10.1108/1741 0401311285309

30. Kaynak, H. (2003). The relationship between total quality management practices and their effects on firm performance. Journal of Operations Management, 21, 405-435. 
31. Kujala, J., \& Lillrank, P. (2004). Total quality management as a cultural phenomenon. Quality Management Journal, 11 (4) 43-55.

32. Lawler, E. (1994). Total quality management and employee involvement: Are they compatible? Academy of Management Executive, 8(1), 68-76.

33. Lawler, E.E. \& Hall, D.T. (1970). Relationship of job characteristics to job involvement, satisfaction and intrinsic motivation. Journal of Applied Psychology, 54(4), 305-312.

34. Leonard, K. E. (2015). The effect of organisational culture in implementing and sustaining lean practices. Journal of Manufacturing Technology Management, 16(5), 725-743.

35. Lewis, W.G., Pun, K.F. \& Lalla, T.R.M. (2006). Exploring soft versus hard factors for TQM implementation in small and medium sized enterprises. International Journal of Productivity and Performance Management, 55(7), 539-554.

36. Manz, C.C. \& Stewart, G.L. (1997). Attaining flexible stability by integrating total quality management and socio-technical systems theory. Organisation Science, 8(1), 59-70.

37. Mehralian, G., Nazari, J., Nooriparto, G., \& Rasekh, H. (2017). TQM and organizational performance using the balanced scorecard approach. International Journal of Productivity and Performance Management, 66 (1), 111-125. doi.org/10.1108/ IJPPM-08-2015-0114

38. Menezes, L. M. De. (2012). Job satisfaction and quality management: An empirical analysis. International Journal of Operations \& Production Management, 32(3), 308-328.

39. Meyer, J. P. \& Allen, N. J. (1991). A threecomponent conceptualisation of commitment. Human Resource Management Review, 1, 61-89.

40. Mohamed, S.I. (2014). The Relationship between Organizational Justice and Quality Performance among Healthcare Workers: A Pilot Study. Scientific World Journal, 2014, doi.org/10.1155/2014/757425

41. Molina-Azorin, J. F., Tari, J. J., Claver-Cortes, E. \& Lopez-Gamero, M. D. (2009). Quality management, environmental management and firm performance: A review of empirical studies and issues of integration. International Journal of Management Reviews, $11(2), 197-222$.

42. Montes J.L., Jover, A. V. \& Fernandez, L.M.M. (2003). Factors affecting the relationship between total quality management and organisational performance. International Journal of Quality \& Reliability Management, 20(2), 189-209.

43. Morrow, P. C. (1997). The measurement of TQM principles and work-related outcomes. Journal of Organisational Behaviour, 18, 363-376.

44. Mosadeghrad, M.S. (2014). Essentials of total quality management: A meta-analysis. International
Journal of Health Care Quality Assurance, 27(6), 544-558.

45. Mosaddegh Rad, M. A., \& Yarmohammadian, H.M. (2006). A study of relationship between managers' leadership style and employees' job satisfaction. Leadership in Health Services, 19 (2), 11-28. Doi/ 10.1108/13660750610665008

46. Nair, A. (2006). Meta-analysis of the relationship between quality management practices and firm performance - Implications for quality management theory development. Journal of Operations Management, 24, 948-975.

47. Ooi, K. B., Arumugam, V. \& Seng Hwa, T. (2005). Does soft TQM predict employees' attitudes? The TQM Magazine, 17(3), 279-289.

48. Ooi, K.B., Abu Bakar, N., Arumugam, V., Vellapan, L. \& Loke, A.K.W. (2007). Does TQM influence employees' job satisfaction? An empirical case analysis. International Journal of Quality \& Reliability Management, 24(1), 62-77.

49. Ooi, K.B., Safa, M.S. \& Arumugam, V. (2006). TQM practices and affective commitment: A case of Malaysian semiconductor packaging organisations. International Journal of Management and Entrepreneurship, 2(1), 37-55.

50. Otoo, F., Otoo, E., Abledu, G., \& Bhardwaj, A. (2019). Impact of human resource development (HRD) practices on pharmaceutical industry's performance. European Journal of Training and Development, 43 (1/2), 188-210. doi.org/10.1108/ EJTD-09-2018-0096

51. Patyal, V.P. \& Koilakuntla, M. (2017). The impact of quality management practices on performance: An empirical study. Benchmarking: An International Journal, 24(2), 511-535.

52. Pool, S. (2000). The learning organization: motivating employees by integrating TQM philosophy in a supportive organizational culture. Leadership \& Organization Development Journal, 21 (8), 373-378. doi.org/10.1108/01437730010379276

53. Powell, T.C. (1995). Total quality management as competitive advantage: A review and empirical study. Strategic Management Journal, 16(1), 15-37.

54. Prajogo, D. \& Cooper, B. K. (2010). The effect of people-related TQM practices on job satisfaction: A hierarchical model. Production Planning \& Control, 21(1), 26-35.

55. Prajogo, D. I. \& Cooper, B. (2017). The individual and organisational level effects of TQM practices on job satisfaction. International Journal of Manpower, 38(2), 215-225.

56. Prajogo, D.I., \& McDermott, C.A. (2011). The relationship between multidimensional organizational culture and performance. International Journal of Operations \& Production Management, 31 (7), 712-735. 
57. Psomas, E., Vouzas, F., \& Kefetzopoulas, D. (2014). Quality management benefits through the "soft" and "hard" aspect of TQM in food companies. The TQM Journal, 26 (5), 431-444.

58. Rahman, S. \& Bullock, P. (2005). Soft TQM, hard TQM, and organisational performance relationships: An empirical investigation. Omega, 33(1), 73-83.

59. Sadikoglu, E. \& Olcay, H. (2014). The Effects of Total Quality Management Practices on Performance and the Reasons of and the Barriers to TQM Practices in Turke. Advances in Decision Sciences, 2014, 5-22. doi: 10.1155/2014/537605

60. Sadikoglu, E. \& Zehir, C., (2010). Investigating the effects of innovation and employee performance on the relationship between total quality management practices and firm performance: An empirical study of Turkish firms. International Journal of Production Economics, 127, 13-26.

61. Shafiq, M., Lasrado, F. \& Hafeez, K. (2017). The effect of TQM on organisational performance: Empirical evidence from the textile sector of a developing country using SEM. Total Quality Management \& Business Excellence, 30 (1-2), doi:: 10.1080/14783363.2017.1283211

62. Sitkin, S., Sutcliffe, K. \& Schroeder, R. (1994). Distinguishing control from learning in total quality management: A contingency perspective. Academy of Management Review, 19(3), 537-564.

63. Sousa, R. \& Voss, C. A. (2002). Quality management re-visited: A reflective review and agenda for future research. Journal of Operations Management, 20, 91-109.

64. Trivellas, P., \& Santouridis, I. (2016). Job satisfaction as a mediator of the relationship between service quality and organisational commitment in higher education. An empirical study of faculty and administration staff. Total Quality Management \& Business Excellence, 27 (1-2), 169-183.

65. Valmohammadi, C. \&Roshanzamir, S. (2015). The guidelines of improvement: Relations among organisational culture, TQM and performance. International Journal of Production Economics, 164, 167-178.

66. Wei, J., Chang, Y.W., Zhang, X., Wu, H. \& Tang, Y. (2017). Performance measurement systems, TQM and multi-level firm performance: A personorganisation fit perspective. Total Quality Management \& Business Excellence, doi: 10.1080/ 14783363.2017.1384311

67. Wickramasinghe, V. (2012). Influence of total quality management on human resource practices: An explanatory study. International Journal of Quality \& Reliability Management, 29(8), 836-850.

68. Yeung, A.D.L., Cheng, T.C.E., \& Lai, K.H. (2005). An empirical model for managing quality in the electronics industry. Production and Operations Management, 14(2), 189-204.
69. Youssef, M.A., \& Youssef, E.M. (2018). The synergistic impact of ISO 9000 and TQM on operational performance and competitiveness. International Journal of Quality \& Reliability Management 35 (3), 614-634. doi:10.1108/IJQRM02-2016-0024

70. Yue, J.W., Ooi, K. \& Keong, C.C. (2011). The relationship between people-related total quality management (TQM) practices, job satisfaction and turnover intention: A literature review and proposed conceptual model. African Journal of Business Management, 5(15), 6632-6639.

71. Zeng, J., Zhang, W., Matsui, Y. \& Zhao, X. (2017). The impact of organisational context on hard and soft quality management and innovation performance. International Journal of Production Economics, 185, 240-251.

72. Zhao, X., Yeung, A. C. L. \& Lee, T. S. (2004). Quality management and organisational context in selected service industries of China. Journal of Operations Management, 22 (6), 575-58.

73. Zu, X., Lawrence D. Fredendall, L.D. \& Douglas, T.J., (2008). The evolving theory of quality management: The role of Six Sigma. Journal of Operations Management, 26, 630-650.

74. Zu, X. (2009). Infrastructure and core quality management practices: How do they affect quality? International Journal of Quality \& Reliability Management, 26(2), 129-149. 